\title{
Import Competition and Market Power: Canadian Evidence
}

by

Aileen J. Thompson

No. 139

11F0019MPE No. 139

ISSN: 1200-5223

ISBN: 0-660-18150-9

Federal Trade Commission

Washington, DC

Email: aileenjt@aol.com

April 2000

This paper represents the views of the author and does not necessarily reflect the opinions of Statistics Canada or the Federal Trade Commission. 


\section{Table of Contents}

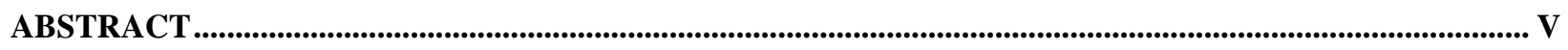

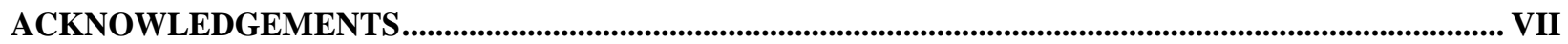

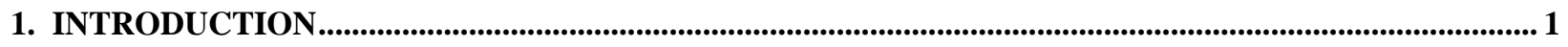

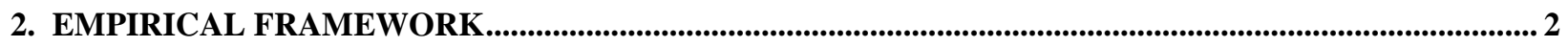

2.1 Estimating Price-Marginal Cost Ratios .............................................................................................. 2

2.2 Estimating the Relationship between Price-Cost Ratios and Import Competition......................................... 3

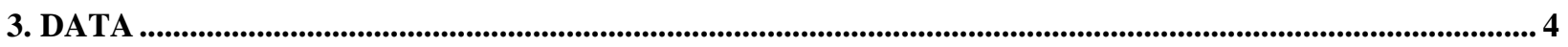

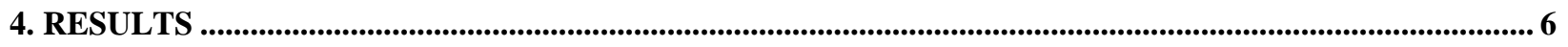

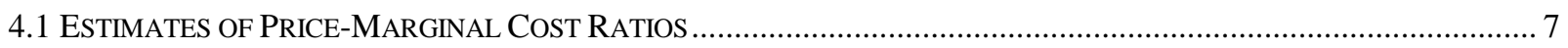

4.2 CROSS-SECTIONAL ANALYSIS: BENCHMARK MODEL................................................................................ 7

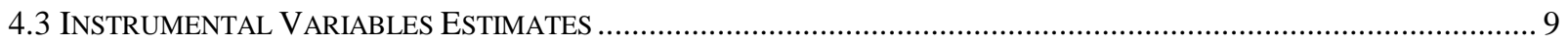

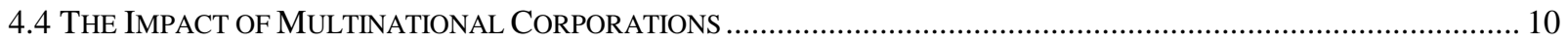

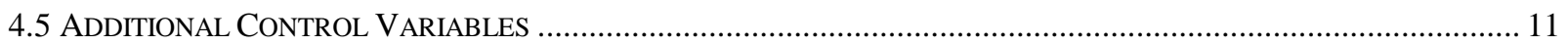

4.6 ANALYSIS BASED ON CHANGES BETWEEN 1971-72 AND 1978-79............................................................ 12

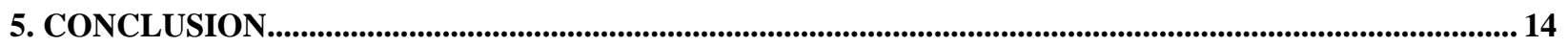

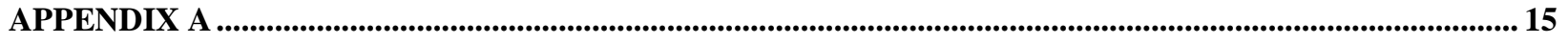

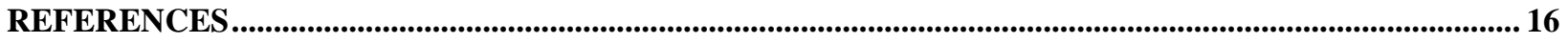




\begin{abstract}
This paper estimates price-marginal cost mark-ups for Canadian manufacturing industries in order to assess the impact of import competition on domestic market power. The results are mixed. Although the overall relationship between mark-ups and imports is positive across industries for the early 1970s and insignificant for the late 1970s, there is some weak crosssectional evidence to suggest that imports reduce market power in domestically concentrated industries. Changes in imports between the two periods, however, have a positive impact on mark-ups in concentrated industries. Thus, there is no consistent evidence for Canada that imports have had the beneficial impact on competition that has been emphasized in much of the literature. In contrast, an interesting result of the paper is that increases in exports are associated with reductions in mark-ups, suggesting that exports may have a stronger pro-competitive impact on domestic firms than imports.
\end{abstract}

Keywords: import competition, market power 


\section{Acknowledgements}

Most of this paper was written while I was an Associate Professor at Carleton University. I am grateful to the Micro-Economic Analysis Division of Statistics Canada for a Visiting Fellowship and support that allowed me to complete this project. I thank Bob Gibson and Joanne Johnson for providing insight into the data and John Baldwin for many thoughtful discussions. I also thank the University of Michigan for providing an interesting research environment during my sabbatical visit, workshop participants at Carleton University, Clark University, Statistics Canada and the General Accounting Office for helpful comments, the Social Science and Humanities Research Council of Canada (SSHRC) for financial support and Ying Kong for research assistance. 


\section{Introduction}

A number of international trade models have now been developed that account for imperfect competition. Although some of these models provide insight into situations where trade protection may be welfare improving, most indicate that imperfect competition provides additional sources of gains from trade. Many of these gains result from the "pro-competitive" effect of trade: import competition increases the perceived elasticity of demand for domestic firms, leading them to reduce their mark-ups of price over marginal cost. ${ }^{1}$

Applied general equilibrium models suggest that these effects may be important quantitatively. Harris (1984) and Cox and Harris (1985) perform a number of simulations of trade liberalization experiments calibrated for 1976 Canadian data. They find that the estimated welfare gains based on models incorporating imperfect competition are substantially greater than the estimated gains based on the corresponding perfectly competitive model. Similarly, in a study of the potential impact of the Canada-United States Free Trade Agreement, Brown and Stern's (1989) model suggests that the pro-competitive effects of Canadian tariff reductions may be quite strong in many Canadian industries.

Early econometric studies analyzing the impact of trade on market power employ the mark-up of price over average variable cost as a measure of non-competitive behavior. These studies generally find that import competition reduces mark-ups, particularly in domestically concentrated industries. $^{2}$ Economic theory, however, predicts that import competition reduces the mark-up of price over marginal cost, which is not directly observable. Recent studies draw on the work of Roberts (1984) and Hall (1988) to estimate price-marginal cost mark-ups from equations derived from profit maximizing conditions. Three studies apply this approach to plantlevel data to analyze the impact of trade reform on competition in developing countries. Levinsohn (1993) finds that price-marginal cost mark-ups fell in Turkish industries where trade was liberalized, and increased in industries where trade protection was increased. Similarly, Harrison (1994) finds that mark-ups are negatively related to import competition in the Côte d'Ivoire, and Krishna and Mitra (1998) present evidence that mark-ups fell during the trade reform period in India.

This paper estimates price-marginal cost ratios using detailed establishment-level data for manufacturing industries in Canada during the 1970s. The 1970s were chosen as the period of study due to the substantial increase in trade during this time. The share of domestic consumption of manufactured goods that was accounted for by imports rose from $26 \%$ in 1971 to $33 \%$ in 1979. The relationship between mark-ups and imports is estimated for two separate cross-sections: the early 1970s and the late 1970s. In addition, the data for the two periods are combined to analyze the impact of changes in import competition on mark-ups over time. The primary conclusion that can be drawn from the analysis is that there is no consistent evidence that import competition has reduced the market power of firms operating in the Canadian market.

\footnotetext{
1 See Markusen (1981).

${ }^{2}$ See, for example, Caves, Porter and Spence (1980), Jacquemin, de Ghellinck and Huveneers (1980), Pugel (1980), De Melo and Urata (1986) and Domowitz, Hubbard, and Petersen (1986) and Katics and Petersen (1994).
} 


\section{Empirical Framework}

\subsection{Estimating Price-marginal Cost Ratios}

Profit-maximization with respect to output yields the following relationship between price and marginal cost:

$$
\frac{P_{i t}}{M C_{i t}}=\left|1+\frac{s_{i t} \theta_{i t}}{\eta_{i t}}\right|^{-1} \equiv \beta_{i t},
$$

where $s_{i t}$ is the market share of the firm, $\eta_{i t}$ is the market elasticity of demand in industry i, and $\theta_{i t}$ is the conjectural variations parameter $\left(=\partial Q_{t} / \partial q_{i t}\right)$. As defined above, $\beta_{i t}$ is the profitmaximizing ratio of price to marginal cost. The estimated value of this parameter can be used to calculate the Lerner index, the mark-up of price over marginal cost:

$$
\frac{P-M C}{P}=1-\frac{1}{\beta} \text {. }
$$

To estimate price-marginal cost ratios, I follow the approach employed by Levinsohn (1993). Consider the production function for a representative firm i:

$$
q_{i t}=\phi_{i t} f\left(L_{i t}\right)
$$

where $\mathrm{L}_{\mathrm{it}}$ is a vector of $j$ factors of production, and $\phi_{i t}$ is a firm- and period-specific productivity shock that is assumed to follow a random walk:

$$
\begin{gathered}
\phi_{i t}=\phi_{i, t-1}+\varepsilon_{i t}, \\
\varepsilon_{i t} \approx N\left(0, \sigma^{2}\right) .
\end{gathered}
$$

Furthermore, it is assumed that $\varepsilon_{i t}$ is composed of a time-specific productivity shock that is common to all firms within a given industry and a productivity shock that is specific to the individual firm:

$$
\varepsilon_{i t}=\lambda_{t}+\mu_{i t}
$$

To derive an estimating equation for $\beta_{i t}$, totally differentiate (2),

$$
d q_{i t}=\phi_{i t}\left[{ }_{j}\left(\partial f_{i t} / \partial L_{j i t}\right) d L_{j i t}\right]+f_{i t}\left(\lambda_{t}+\mu_{i t}\right) .
$$

Profit-maximization with respect to input markets implies that the firm employs each input until its marginal revenue product is equal to its price. Thus,

$$
\phi_{i t} p_{i t} \frac{\partial f_{i t}}{\partial L_{i j t}} \beta^{-1}=w_{i j t},
$$


Solving (4) for $\left(\partial f_{i t} / \partial L_{i t}\right)$ and substituting it into (3) yields:

$$
d q_{i t}=\beta_{i t} \frac{w_{i j t}}{p_{t}} d L_{i j t}+f_{i t}\left(\lambda_{t}+\mu_{i t}\right) .
$$

Thus, $\beta_{i t}$ can be estimated by estimating the relationship between changes in output and factor price-weighted changes in inputs.

Price-marginal cost mark-ups are estimated for individual Canadian industries at the 3-digit Standard Industrial Classification (SIC) level for two years during the early 1970s and two years during the late 1970s. Following Levinsohn, three econometric issues are addressed. First, the term $\lambda_{t}$ is modeled as a time-period fixed effect. ${ }^{3}$ Second, the output price, $p_{t}$, is potentially endogenous since an individual firm (and shocks affecting that firm) may affect the industry price level. To address this concern, the wholesale price index is used as an instrument for the industry-level price index. The final concern is that the disturbance term of equation (5), $f_{i t}\left(\lambda_{t}+\mu_{i t}\right)$, is heteroskedastic owing to the presence of the $f_{i t}$ term, which is a function of firm size. To address this issue, it is assumed in the estimation that the variance of the disturbance is proportional to the square of labour expenditures.

\subsection{Estimating the Relationship between Price-cost Ratios and Import Competition}

In the second stage of the analysis, the impact of import competition on price-marginal cost ratios is estimated. It is assumed that the relationship between price-cost ratios, imports and other explanatory variables can be expressed as:

$$
\beta_{h}=\gamma_{k} x_{h k}+v_{h}
$$

where $\beta_{h}$ is the ratio of price to marginal cost for industry $\mathrm{h}, x$ is a vector of industry characteristics, including a measure of import competition, and $v_{h}$ is the disturbance term, assumed to have a zero mean and constant variance of $\sigma_{v}^{2}$.

In addition to import competition, two other industry characteristics are included in the benchmark regression: export intensity and domestic market concentration. As discussed by Caves (1985), theoretical models lead to ambiguous predictions about the impact of exports on profitability. Due to the high correlation between imports and exports (see below), it is important to control for the potential impact of exports so that the impact of imports can be isolated.

\footnotetext{
${ }^{3}$ It is likely that $\lambda_{t}$ is correlated with the changes in inputs. In this case, the fixed effects specification will lead to unbiased and consistent, but inefficient estimates. An alternative approach is to employ instrumental variables estimation although, as discussed by Levinsohn, appropriate instruments are not readily available.
} 
Domestic concentration is employed to control for the degree of competition in the domestic market. It is well known that it is difficult to capture differences in market structure by a single measure (or a manageable set of measures). ${ }^{4}$ The four-firm concentration ratio is the most frequently employed indicator of domestic competition for studies of import competition and profitability and is therefore used here for comparability. ${ }^{5}$

The fact that price-marginal cost ratios are estimated (with error) rather than observed raises the issue of heteroskedasticity. Replacing $\beta_{h}$ with $\hat{\beta}_{h}$, we have the following equation,

$$
\hat{\beta}_{h}=\gamma_{k} x_{h k}+\omega_{h}
$$

where $\omega_{h}=v_{h}+\xi_{h}$, and $\xi_{h}$ is the estimation error of $\hat{\beta}_{h}$. The disturbance term is likely to be heteroskedastic owing to the fact that the variance of $\xi_{h}$ is not constant across industries. Equation 6' is therefore estimated using feasible generalized least squares (GLS) following the procedure described in Appendix A.

\section{Data}

Price-marginal cost ratios are estimated for individual Canadian industries at the 3-digit Standard Industrial Classification (SIC) level over the periods 1971-72 and 1978-79 (based on changes from 1970-71 and 1971-72 for the first period and 1977-78 and 1978-79 for the second period). Data for two years are combined for each estimate to reduce the sensitivity of the estimates to the particular year chosen as well as to increase the number of observations for each 3-digit industry.

To estimate equation (5), price and quantity data are required for output and factors of production. Five factors of production were initially considered: production workers, nonproduction workers, materials, fuel, and capital. Establishment-level data were obtained from the annual Census of Manufactures survey for: value of manufacturing production, hours worked by production workers, number of non-production workers, value of materials used in manufacturing production, and expenditures on fuel and energy. This survey covers every establishment assigned to the manufacturing sector. However, only establishments for which manufacturing activity accounts for at least $90 \%$ of total activity and for which there were no missing data for at least two consecutive years are included in the estimation. In addition, the analysis for each time period is based on the industries that had at least 20 observations. The final sample for which all data are available (including the international trade variables and other industry characteristics) consists of 97 industries for 1971-72 and 99 industries for 1978-79.

\footnotetext{
${ }^{4}$ See Bresnahan (1989) for a discussion of this issue.

${ }^{5}$ For previous versions of the paper, the model was also estimated using market share turnover between 1970 and 1980 as a measure of domestic competition. This variable is measured as the percentage shift of market share from declining establishments to growing establishments. The results were not substantially altered.
} 
Data for capital investment were obtained from the Statistics Canada Capital Expenditures Survey. When the capital expenditures file was merged with the Census of Manufactures file, however, the sample size was significantly reduced. Preliminary analysis indicated that including capital as a factor of production did not significantly alter the estimates of the mark-ups for the sample of plants for which capital data were available. ${ }^{6}$ Capital was therefore not included as a factor of production in the estimates below so that a larger sample could be used.

Quantities for production, materials, and fuel were computed by dividing the values of these variables by industry-level price indices. These indices were obtained from the KLEMS database, made available through the Productivity Group of Statistics Canada. Industry-level wages and salaries were calculated for each 3-digit SIC code by dividing total wages earned by production workers by the number of hours worked and by dividing total salaries earned by nonproduction workers by the number of non-production workers.

Data on imports and exports at the 3-digit SIC level were obtained from the publication, Commodity Trade by Industrial Sector, Historical Summary, 1966-1983, published by the Department of Regional Industrial Expansion, Canada. Both the import and export data were corrected for re-exports. Import intensity is defined as the share of domestic consumption accounted for by imports, where domestic consumption is calculated as (domestic shipments exports + imports). Export intensity is defined as the ratio of exports to shipments. The shipments data were obtained from the Statistics Canada publication Manufacturing Industries in Canada.

Table 1 summarizes the trade data by major manufacturing groups for the 3-digit industries considered in this study. ${ }^{7}$ Both import and export intensities increased in almost every major industry group. ${ }^{8}$ As a result, the pattern of trade across industries is similar for both periods. This suggests, unfortunately, that it may be difficult to distinguish a differential impact of increased trade over the period on mark-ups. The industries with the greatest import intensities in both the 1971-72 period and the 1978-79 period are leather, textiles, knitting mills, primary metals, machinery, transportation equipment, electrical equipment, and chemicals. Three of these industries, primary metals machinery, and transportation equipment, are also among the industries with the largest export intensities. The correlations between import and export intensities are 0.55 and 0.50 for the $1971-72$ and 1978-79 periods, respectively.

Unless otherwise specified, the data were provided by the Micro-Economic Analysis Division of Statistics Canada.

\footnotetext{
6 The correlations between the mark-ups estimated with and without capital were $97.8 \%$ and $98.8 \%$ for 1971 and 1979, respectively.

${ }^{7}$ The data in this table represent only the 3-digit industries used in this study and therefore do not correspond directly to trade data calculated at the 2-digit level.

${ }^{8}$ The exceptions are petroleum and coal, where import intensity fell and knitting mills where export intensities fell.
} 
Table 1. Mean Import and Export Intensities by Major Industry Group

\begin{tabular}{|l|r|r|r|r|}
\hline \multirow{2}{*}{ Industry } & \multicolumn{2}{|c|}{ Import Intensity } & \multicolumn{2}{|c|}{ Export Intensity } \\
\cline { 2 - 4 } & $1971-72$ & $1978-79$ & $1971-72$ & $1978-79$ \\
\hline Food and Beverage Industries & 0.090 & 0.130 & 0.142 & 0.172 \\
Tobacco Products Industries & 0.016 & 0.022 & 0.008 & 0.008 \\
Rubber and Plastic Products & 0.179 & 0.227 & 0.048 & 0.106 \\
Leather Industries & 0.264 & 0.351 & 0.076 & 0.095 \\
Textile Industries & 0.232 & 0.280 & 0.041 & 0.059 \\
Knitting Mills & 0.184 & 0.235 & 0.018 & 0.014 \\
Clothing Industries & 0.090 & 0.130 & 0.098 & 0.099 \\
Wood Industries & 0.082 & 0.127 & 0.184 & 0.245 \\
Furniture and Fixture Industries & 0.060 & 0.101 & 0.045 & 0.094 \\
Paper and Allied Industries & 0.072 & 0.087 & 0.259 & 0.266 \\
Printing and Publishing & 0.145 & 0.162 & 0.022 & 0.034 \\
Primary Metal Industries & 0.233 & 0.301 & 0.440 & 0.458 \\
Metal Fabricating Industries & 0.135 & 0.150 & 0.054 & 0.083 \\
Machinery Industries & 0.630 & 0.668 & 0.344 & 0.383 \\
Transportation Equipment & 0.359 & 0.362 & 0.372 & 0.385 \\
Electrical Product Industries & 0.256 & 0.348 & 0.111 & 0.155 \\
Non-Metallic Mineral Products & 0.182 & 0.193 & 0.133 & 0.163 \\
Petroleum and Coal Products & 0.079 & 0.033 & 0.043 & 0.085 \\
Chemical Products & 0.214 & 0.251 & 0.086 & 0.127 \\
Miscellaneous Manufacturing & 0.370 & 0.408 & 0.155 & 0.165 \\
& & & & \\
\hline
\end{tabular}

Note: These data summarize the import and export intensities of the 3-digit industries included in this study and therefore do not correspond directly to trade data calculated at the 2-digit level.

Table 2. Summary Statistics Price-Marginal Cost Ratios

\begin{tabular}{|l|crr|r|}
\hline & \# Obs & Mean & $\begin{array}{c}\text { Standard } \\
\text { Deviation }\end{array}$ & \multicolumn{1}{|c|}{$\begin{array}{r}\text { Implied } \\
\text { Mark-up }\end{array}$} \\
\hline Panel A: 1971-72 Period & & & & \\
Full Sample & 97 & 1.146 & 0.182 & 0.127 \\
Significantly greater than one & 68 & 1.225 & 0.134 & 0.184 \\
Not significantly different from one & 24 & 1.012 & 0.072 & 0.012 \\
Significantly less than one & 5 & 0.724 & 0.174 & -0.381 \\
& & & & \\
Panel B: 1978-79 Period & & & & \\
Full Sample & 99 & 1.094 & 0.219 & 0.086 \\
Significantly greater than one & 44 & 1.262 & 0.149 & 0.208 \\
Not significantly different from one & 42 & 1.023 & 0.129 & 0.022 \\
Significantly less than one & 13 & 0.756 & 0.103 & -0.323 \\
& & & & \\
Panel C: Change Between Two Periods & & & & \\
Full Sample & 97 & -0.057 & 0.279 & \\
Significant increases & 15 & 0.329 & 0.196 & \\
No significant change & 54 & -0.020 & 0.178 & \\
Significant decrease & 28 & -0.335 & 0.171 & \\
\hline
\end{tabular}

Note: Significance refers to statistic significance at the 5\% level. 


\section{Results}

\subsection{Estimates of Price-marginal Cost Ratios}

Before discussing the results with respect to import competition, it is useful to summarize the estimates of the price-marginal cost ratios. Table 2 reports the summary statistics for both the 1971-72 and 1978-79 periods. The mean estimated price-marginal cost ratio for 1971-72 is 1.15 while the mean estimate for 1978-79 is 1.09, indicating a fall in the average mark-up from $12.7 \%$ to $8.6 \%$. This is within the range of estimates reported by other studies based on plant-level data. Harrison (1994), for example, reports an average mark-up across sectors of $8 \%$.

Owing to the significant increase in trade during the 1970s, the general reduction in estimated price-marginal cost ratios during this period is consistent with the hypothesis that trade increases competition. In addition, the proportion of industries with ratios that were statistically significantly greater than one fell from $70 \%$ to $44 \%$. The increase in competition is not uniform, however. Panel $\mathrm{C}$ of Table 2 provides summary statistics for the change in price-marginal cost ratios. Although $29 \%$ of the industries experienced a statistically significant decline in their mark-ups, $15 \%$ actually experienced a statistically significant increase. ${ }^{9}$

Table 3 summarizes the 3-digit mark-ups according to 2-digit industry groups. Six industries had average ratios above the median for both the early 1970s and the late 1970s: tobacco products, electrical products, non-metal mineral products, petroleum and coal, rubber and plastic, and miscellaneous; while six industries had average ratios below the median for both periods: paper and related products, wood products, clothing, printing and publishing, knitting mills, and food and beverages.

\subsection{Cross-sectional Analysis: Benchmark Model}

Table 4 presents the GLS results of equation (6') estimated separately for 1971-72 and 1978-79. The overall impact of import competition on price-marginal cost ratios is actually positive columns 1 and 3 for both periods, although only the estimate for 1971-72 is statistically significant. This finding is inconsistent with the hypothesis that imports increase competition in the domestic market and is in contrast to the results of similar studies that are based on developing countries (e.g., Levinsohn (1993) and Harrison, 1994).

As will be discussed more fully below, the non-negative relationship between mark-ups and import competition may reflect, in part, the simultaneity problem that high mark-ups attract imports. Another potential explanation is that the overall Canadian domestic economy is sufficiently competitive that import competition does not have a significant impact. Import competition can be expected to have the greatest impact on industries where domestic market conditions are such that competition would otherwise be weak. When the interaction between imports and concentration is included in the estimation equation columns 2 and 4 , the coefficient on this variable is negative as predicted, although not statistically significant.

\footnotetext{
${ }^{9}$ To estimate the correct standard errors, the data were combined for the two periods and a dummy variable was employed to capture the change in mark-ups with the corresponding standard error.
} 
Table 3. Mean Mark-ups for Major Industry Groups

\begin{tabular}{|l|c|r|r|r|r|}
\hline & \multirow{2}{*}{ \#Obs. (a) } & \multicolumn{2}{|c|}{$1971-72$} & \multicolumn{2}{|c|}{$1978-79$} \\
\cline { 3 - 5 } & & $\begin{array}{c}\text { Price/Cost } \\
\text { Ratio }\end{array}$ & $\begin{array}{c}\text { Implied } \\
\text { Mark-up }\end{array}$ & $\begin{array}{r}\text { Price/Cost } \\
\text { Ratio }\end{array}$ & \multicolumn{1}{|c|}{$\begin{array}{l}\text { Implied } \\
\text { Mark-up }\end{array}$} \\
\hline Food and Beverage Industries & 9 & 1.063 & 0.059 & 1.074 & 0.069 \\
Tobacco Products Industries & 1 & 1.374 & 0.272 & 1.641 & 0.391 \\
Rubber and Plastic Products & 2 & 1.130 & 0.115 & 1.272 & 0.214 \\
Leather Industries & 3 & 1.099 & 0.090 & 1.215 & 0.177 \\
Textile Industries & 7 & 1.113 & 0.101 & 1.076 & 0.070 \\
Knitting Mills & 2 & 1.108 & 0.098 & 0.999 & -0.001 \\
Clothing Industries & 6 & 1.089 & 0.082 & 0.959 & -0.043 \\
Wood Industries & 6 & 1.091 & 0.083 & 1.100 & 0.091 \\
Furniture and Fixture Industries & 4 & 1.067 & 0.063 & 1.193 & 0.162 \\
Paper and Allied Industries & $3(4)$ & 1.092 & 0.084 & 0.851 & -0.175 \\
Printing and Publishing & 3 & 1.027 & 0.027 & 1.012 & 0.012 \\
Primary Metal Industries & 7 & 1.065 & 0.061 & 1.127 & 0.113 \\
Metal Fabricating Industries & 8 & 1.179 & 0.152 & 1.032 & 0.031 \\
Machinery Industries & 3 & 1.285 & 0.222 & 1.098 & 0.089 \\
Transportation Equipment & 5 & 1.112 & 0.101 & 1.137 & 0.121 \\
Electrical Product Industries & 6 & 1.247 & 0.198 & 1.185 & 0.156 \\
Non-Metallic Mineral Products & $8(9)$ & 1.250 & 0.200 & 1.105 & 0.095 \\
Petroleum and Coal Products & 2 & 1.158 & 0.136 & 1.238 & 0.192 \\
Chemical Products & 7 & 1.282 & 0.220 & 1.028 & 0.027 \\
Miscellaneous Manufacturing & 5 & 1.183 & 0.155 & 1.172 & 0.146 \\
\hline
\end{tabular}

(a) The number of 3-digit industries included in each major industry group. The numbers in parenthese indicate the number of industries for 1978-79 when different from the 1971-72 period.

Table 4. Results

\begin{tabular}{|c|c|c|c|c|c|c|c|c|}
\hline & \multicolumn{4}{|c|}{ GLS Estimates } & \multicolumn{4}{|c|}{ IV Estimates } \\
\hline & \multicolumn{2}{|c|}{$1971-72$} & \multicolumn{2}{|c|}{$1978-79$} & \multicolumn{2}{|c|}{$1971-72$} & \multicolumn{2}{|c|}{$1978-79$} \\
\hline & (1) & (2) & (3) & (4) & (5) & (6) & (7) & (8) \\
\hline \multirow[t]{2}{*}{ Imports } & $0.243 *$ & 0.444 & 0.122 & 0.423 & 0.224 & 1.045 & -0.394 & -0.076 \\
\hline & $(0.113)$ & $(0.228)$ & $(0.129)$ & $(0.252)$ & $(0.337)$ & $(0.710)$ & $(0.422)$ & $(0.770)$ \\
\hline \multirow[t]{2}{*}{ Imports*C4 } & & -0.436 & & -0.687 & & -1.255 & & -0.468 \\
\hline & & $(0.432)$ & & $(0.494)$ & & $(0.993)$ & & (1.107) \\
\hline \multirow[t]{2}{*}{ C4 } & 0.043 & 0.129 & $0.284 *$ & $0.453 *$ & 0.046 & 0.292 & $0.299 *$ & 0.410 \\
\hline & $(0.081)$ & $(0.117)$ & $(0.100)$ & $(0.157)$ & $(0.081)$ & $(0.211)$ & $(0.108)$ & $(0.285)$ \\
\hline \multirow[t]{2}{*}{ Exports } & -0.118 & -0.084 & -0.224 & -0.182 & -0.111 & -0.134 & 0.015 & -0.009 \\
\hline & (0.106) & $(0.111)$ & $(0.124)$ & (0.128) & (0.187) & $(0.195)$ & $(0.230)$ & $(0.219)$ \\
\hline \multirow[t]{2}{*}{ Constant } & $1.101 *$ & $1.060 *$ & $0.981 *$ & $0.905^{*}$ & $1.102 *$ & $0.955^{*}$ & $1.052 *$ & $0.985^{*}$ \\
\hline & (0.038) & $(0.055)$ & $(0.050)$ & $(0.073)$ & $(0.053)$ & $(0.124)$ & $(0.076)$ & $(0.163)$ \\
\hline Hausman Statistic & & & & & 0.004 & 0.870 & 1.644 & 1.017 \\
\hline
\end{tabular}

Note: Results are based on feasible generalized least squares estimation following the procedure described in Appendix A. Standard errors are in parentheses.

* Statistically significant at the 5\% level. 
The relationship between mark-ups and export intensity is negative for all of the equations in Table 4. Although not statistically significant, the negative relationship is consistent with the hypothesis that participation in export markets places competitive pressure on domestic exporting firms. Harrison's (1994) estimates of mark-ups in different sectors of the food industry also suggest that export exposure has a pro-competitive impact.

The results in Table 4 indicate that domestic concentration did not have a significant impact on price-marginal cost ratios for the 1971-72 period. It did, however, have a significant positive impact for the 1978-79 period. It is interesting that the estimated effect is stronger for the 197879 period. Due to the increase in international trade during the 1970s, one could predict that the level of domestic concentration would have been less important in the late 1970s than in the early 1970s. This result may reflect the weakness of using a single measure to capture the complex variations in market structure.

For purposes of comparison, Domowitz, Hubbard, and Petersen (1988) find that concentration has a small, but significant, positive impact on estimated price-marginal cost mark-ups for U.S. manufacturing industries. When the analysis is performed for different types of industries, however, they find that the relationship between concentration and mark-ups is strong for consumer goods and durable goods industries, but insignificant for producer goods and nondurable goods industries. In addition, they find that the relationship varies over the business cycle.

\subsection{Instrumental Variables Estimates}

As mentioned above, there is a potential simultaneity between price-cost ratios and imports. If imports are determined endogenously, then the GLS estimates will be biased. Instrumental variables estimates are reported in columns 5-8 in Table 4. Appropriate instruments are correlated with imports, but uncorrelated with the error term of equation (6'). The set of excluded instruments consists of the tariff rate and dummy variables for natural resource and labour intensive industries. ${ }^{10}$ Interactions between these instruments and concentration are also included as instruments for the estimation equations that include the interaction between concentration and imports. An alternative set of regressions was estimated using the effective rate of protection as an instrument in place of the nominal tariff rate. The results were very similar to those discussed below. ${ }^{11}$

As discussed by Bound, Jaeger and Baker (1995), the finite sample bias of IV estimates may be quantitatively important when the correlation between the endogenous variables and the instruments is weak. In particular, a good approximation of the bias of IV estimates relative to OLS estimates is provided by $(1 / \mathrm{F})$, where $\mathrm{F}$ is the $\mathrm{F}$ statistic for the excluded instruments in the first stage regression. The F-statistics for the excluded instruments employed here range from 2.1 to 4.4 , indicating that the potential bias of the IV estimates is small relative to the OLS estimates.

\footnotetext{
${ }^{10}$ The tariff data were generously provided by Larry Schembri. The labour and natural resource dummy variables are based on the OECD (1987) taxonomy adapted for the Canadian economy by Baldwin and Raffiquzzaman (1994). ${ }^{11}$ Effective rates of protection measures were generously provided by John Baldwin for 1970 and 1978.
} 
The IV results are reported in columns 5 through $8 .^{12}$ The IV estimates differ in magnitude from the OLS estimates and are estimated with larger standard errors. The implications of the results, however, are similar. Based on the Hausman test, the hypothesis that the two sets of estimates are the same cannot be rejected at the 5\% level of significance for any of the estimating equations. Therefore, the hypothesis that imports are exogenous cannot be rejected.

\subsection{The Impact of Multinational Corporations}

In this section, the role of multinational corporations in determining the relationship between import competition and mark-ups is examined. This is motivated by theoretical and applied general equilibrium work by Markusen, Rutherford, and Hunter (1995) that suggests that the procompetitive effect of trade may be dampened by the presence of multinational corporations. This is because an increase in imports may actually increase the market share and mark-up of foreignowned firms operating in the domestic market if imports originate from the parent company. In this case, trade liberalization will not necessarily have the overall pro-competitive effect that has been emphasized in much of the trade policy literature.

This is a potentially important issue in Canada. It has been estimated that foreign-controlled importers accounted for approximately $70 \%$ of Canadian imports in $1978 .{ }^{13}$ To investigate the impact of multinational corporations on the potential pro-competitive effects of trade, the estimation equation is augmented to include an interaction term between imports, domestic concentration, and a measure of foreign ownership. The prediction is that the coefficient on this variable will be positive, indicating that foreign ownership weakens the potential for imports to increase competition in domestically concentrated industries. The percentage of industry imports that were imported by foreign controlled firms is used as the measure of the importance of foreign ownership. Unfortunately this variable is only available for $1978 .{ }^{14}$ The 1978 value is used for both time periods based on the assumption that it was relatively stable over time. ${ }^{15}$

The results of the augmented regression are reported in columns 2 and 6 in Table 5. The coefficient on the interaction between imports, concentration, and foreign ownership is positive as predicted, although not statistically significant. Comparing these results to the benchmark model (repeated in columns 1 and 4), the coefficient on the interaction between imports and concentration becomes larger in absolute value and is marginally significant at the $10 \%$ level for the 1971-72 period. These results provide some, albeit weak, evidence that the potential disciplining effect of imports is diminished in industries with a relatively high degree of foreign ownership. This is consistent with the predictions of Markusen, Rutherford, and Hunter (1995), and has not previously been tested.

\footnotetext{
12 The IV estimates are also based on GLS estimation to account for the fact that the mark-ups are estimated with error.

${ }^{13}$ Statistics Canada (1978) Canadian imports by domestic and foreign controlled enterprises, Catalogue 67-509 Occasional. Ottawa: Minister of Supply and Services, Canada.

${ }^{14}$ Statistics Canada (1978) Canadian imports by domestic and foreign controlled enterprises, Catalogue 67-509 Occasional. Ottawa: Minister of Supply and Services, Canada.

${ }^{15}$ Alternatively, the equations were estimated using a dummy variable indicating whether the value of this variable was greater than the mean. The results were not significantly affected.
} 


\subsection{Additional Control Variables}

In this section, the estimation equation is augmented further to include three additional control variables. The first is demand growth, which is defined to be the industry-level percentage change in demand during the relevant periods. For the 1971-72 period, for example, it is the percentage change between 1972 and $1970 .{ }^{16}$ The other two control variables capture possible entry barriers. The first is the capital/revenue ratio ${ }^{17}$, and the second is a dummy variable indicating industries that are characterized by differentiated products. ${ }^{18}$ The latter variable is motivated by the idea that firms in differentiated products industries may create entry barriers by making strategic investments in R\&D and advertising. Martins, Scarpetta and Pilat (1996) find that mark-ups in OECD countries tend to be higher in "high" differentiation industries than in "low" differentiation industries.

The results are presented in columns 3 and 6 in Table 5. None of the coefficients for the growth or product differentiation variables are statistically significant. The coefficient on the capital stock variable is positive as predicted, but statistically insignificant, for 1971-72 and is actually negative (and significant) for the 1978-79 period. Similar results are obtained when capital share estimates from the KLEMS database are used as an alternative measure of the importance of fixed capital. ${ }^{19}$ The important point to note from these results is that the conclusions with respect to the international trade variables are not affected by the addition of these variables.

\footnotetext{
${ }^{16}$ Domestic demand is defined as (domestic shipments-exports+imports) and is calculated at the 2-digit level to minimize potential endogeneity problems. The data were taken from the Statistics Canada publication, Manufacturing Trade and Measures, 1966-1984. Quantities were deflated by industry-level price indices calculated from the KLEMS database.

${ }^{17}$ Net capital stock data were obtained from the Statistics Canada publication, Fixed Capital Stocks and Flows, 1972-1979. These data are not available for 1971 and are only available at the 2-digit level for the years 1972-79 for the relevant industry codes. The 1972 value is employed for the analysis of the 1971-72 period and the average of the 1978 and 1979 values are employed for the 1978-79 period.

${ }^{18}$ This dummy variable is based on the taxonomy adopted by Baldwin and Raffiquzzaman (1994).

19 As noted by Schmalensee (1989), studies of margins based on average variable cost have generally found a positive relationship between margins and the capital/output ratio. There have been some findings, however, of a significant negative relationship.
} 
Table 5. Extended Analysis

\begin{tabular}{|c|c|c|c|c|c|c|c|c|}
\hline & \multicolumn{4}{|c|}{ 1971-72 } & \multicolumn{4}{|c|}{ 1978-79 } \\
\hline & (1) & (2) & (3) & (4) & (5) & (6) & (7) & (8) \\
\hline Imports & $\begin{array}{r}0.444 \\
(0.228)\end{array}$ & $\begin{array}{c}0.525^{*} \\
(0.230)\end{array}$ & $\begin{array}{c}0.523^{*} \\
(0.230)\end{array}$ & $\begin{array}{c}0.497 * \\
(0.248)\end{array}$ & $\begin{array}{c}0.423 * \\
(0.252)\end{array}$ & $\begin{array}{c}0.434^{*} \\
(0.255)\end{array}$ & $\begin{array}{c}0.440 * \\
(0.257)\end{array}$ & $\begin{array}{r}0.278 \\
(0.271)\end{array}$ \\
\hline Imports*C4 & $\begin{array}{r}-0.436 \\
(0.432) \\
\end{array}$ & $\begin{array}{r}-1.064 \\
(0.573) \\
\end{array}$ & $\begin{array}{r}-0.985 \\
(0.575)\end{array}$ & $\begin{array}{r}-0.435 \\
(0.471)\end{array}$ & $\begin{array}{r}-0.687 \\
(0.494) \\
\end{array}$ & $\begin{array}{r}-0.815 \\
(0.653) \\
\end{array}$ & $\begin{array}{r}-0.816 \\
(0.656) \\
\end{array}$ & $\begin{array}{r}-0.680 \\
(0.509)\end{array}$ \\
\hline Imports*C4* Fimp & & $\begin{array}{r}0.718 \\
(0.481) \\
\end{array}$ & $\begin{array}{r}0.676 \\
(0.480) \\
\end{array}$ & & & $\begin{array}{r}0.248 \\
(0.543) \\
\end{array}$ & $\begin{array}{r}0.242 \\
(0.546) \\
\end{array}$ & \\
\hline Imports*C4* Entry & & & & $\begin{array}{r}-1.693 \\
(6.173) \\
\end{array}$ & & & & $\begin{array}{r}8.163 \\
(7.446) \\
\end{array}$ \\
\hline $\mathrm{C} 4$ & $\begin{array}{r}0.129 \\
(0.117) \\
\end{array}$ & $\begin{array}{r}0.174 \\
(0.119) \\
\end{array}$ & $\begin{array}{r}0.179 \\
(0.119) \\
\end{array}$ & $\begin{array}{r}0.073 \\
(0.189) \\
\end{array}$ & $\begin{array}{c}0.453 * \\
(0.157)\end{array}$ & $\begin{array}{c}0.424^{*} \\
(0.159)\end{array}$ & $\begin{array}{c}0.429 * \\
(0.162)\end{array}$ & $\begin{array}{c}0.806^{*} \\
(0.223)\end{array}$ \\
\hline C4*Entry & & & & $\begin{array}{r}1.419 \\
(3.785) \\
\end{array}$ & & & & $\begin{array}{c}-9.894 * \\
(4.591)\end{array}$ \\
\hline Entry & & & & $\begin{array}{r}-0.841 \\
(1.360) \\
\end{array}$ & & & & $\begin{array}{c}3.769^{*} \\
(1.604)\end{array}$ \\
\hline Exports & $\begin{array}{r}-0.084 \\
(0.111) \\
\end{array}$ & $\begin{array}{r}-0.092 \\
(0.110) \\
\end{array}$ & $\begin{array}{r}-0.083 \\
(0.110) \\
\end{array}$ & $\begin{array}{r}-0.089 \\
(0.115) \\
\end{array}$ & $\begin{array}{r}-0.182 \\
(0.128) \\
\end{array}$ & $\begin{array}{r}-0.177 \\
(0.128) \\
\end{array}$ & $\begin{array}{r}-0.171 \\
(0.131) \\
\end{array}$ & $\begin{array}{r}-0.192 \\
(0.127)\end{array}$ \\
\hline Growth & & & $\begin{array}{r}-0.347 \\
(0.270)\end{array}$ & & & & $\begin{array}{r}-0.043 \\
(0.191)\end{array}$ & \\
\hline Constant & $\begin{array}{c}1.060 * \\
(0.055)\end{array}$ & $\begin{array}{c}1.046^{*} \\
(0.055)\end{array}$ & $\begin{array}{c}1.089^{*} \\
(0.065)\end{array}$ & & $\begin{array}{c}0.905^{*} \\
(0.073)\end{array}$ & $\begin{array}{c}0.915^{*} \\
(0.074)\end{array}$ & $\begin{array}{c}0.909^{*} \\
(0.074)\end{array}$ & $\begin{array}{l}0.734^{*} \\
(0.123)\end{array}$ \\
\hline
\end{tabular}

Note: Results are based on feasible generalized least squares estimation following the procedure described in Appendix A. Standard errors are in parentheses.

* Statistically significant at the 5\% level.

Table 6. Results Based on Changes Between 1978-79 and 1971-72

\begin{tabular}{|l|rrrr|}
\hline & $(1)$ & $(2)$ & \multicolumn{1}{l}{$(3)$} & \multicolumn{1}{c|}{$(4)$} \\
\hline Import Intensity & 0.487 & -1.159 & -1.023 & -1.166 \\
& $(0.577)$ & $(1.107)$ & $(1.112)$ & $(1.134)$ \\
\hline Imports*C4 & & 3.730 & 3.281 & 3.888 \\
& & $(2.151)$ & $(3.599)$ & $(3.712)$ \\
\hline Imports*C4*Foreign Ownership & & & 0.499 & 0.262 \\
& & & $(4.218)$ & $(4.244)$ \\
\hline Export Intensity & $-1.098^{*}$ & $-1.111^{*}$ & $-1.215^{*}$ & $-1.128 *$ \\
& $(0.492)$ & $(0.486)$ & $(0.480)$ & $(0.488)$ \\
\hline Demand Growth & & & & -0.166 \\
& & & & $(0.239)$ \\
\hline Constant & -0.051 & -0.046 & -0.054 & -0.055 \\
& $(0.034)$ & $(0.034)$ & $(0.034)$ & $(0.034)$ \\
\hline
\end{tabular}

Note: Results are based on feasible generalized least squares estimation following the procedure described in Appendix A. Standard errors are in parentheses.

* Statistically significant at the $5 \%$ level. 


\subsection{Analysis Based on Changes Between 1971-72 and 1978-79}

A well-known problem with cross-sectional analysis of industry performance is that there are likely to be important industry characteristics that are either unobservable or difficult to measure. ${ }^{20}$ If unobserved characteristics are correlated with the explanatory variables, then the cross-sectional estimates will be biased. If industry effects are relatively time invariant, estimation based on changes over time can control for these fixed effects. As discussed above, however, because trade increased in almost all industries, it may be difficult to distinguish a differential impact of increased trade over the period on mark-ups.

Table 6 presents the results based on changes between the 1978-79 period and the 1971-72 period. Unless otherwise specified, all variables are expressed in terms of differences between these two periods. Following Katics and Petersen (1994), it is assumed that all industry characteristics other than the international trade variables are constant over time. This includes the domestic concentration ratio. ${ }^{21}$

As seen in column 1, the overall impact of import competition on mark-ups is positive, but not significant. This is consistent with the cross-sectional results discussed above. In column 2, the interaction between the concentration ratio and changes in imports is included to determine whether import competition had a differential impact between concentrated and unconcentrated industries. ${ }^{22}$ The coefficient on this interaction term is positive and marginally significant at the $10 \%$ level. Therefore, in contrast to the cross-sectional results, the results here indicate that imports may have actually increased mark-ups in domestically concentrated industries. The implications of these results are not changed when the estimation controls for the impact of multinational imports column 3 or differences in growth rates between the two periods column 4 .

To pursue these results further, the equations were estimated for the subsample of industries for which the 1971-72 price-marginal cost ratio was statistically significantly greater than one. These are the industries where one would expect increased import competition to have the greatest effect. The results were generally the same as those reported in Table 6: there is no evidence that increased imports led to a reduction in mark-ups.

An interesting result from Table 6 is that the coefficient for changes in exports is negative and statistically significant at the 5\% level for all four estimations. The negative relationship between mark-ups and export orientation is consistent with the cross-sectional results and suggests that participation in export markets has a pro-competitive impact on domestic Canadian firms.

\footnotetext{
${ }^{20}$ See Bresnahan (1989) and Schmalensee (1989) for discussions.

${ }^{21}$ The domestic concentration ratio is relatively constant. The sample mean of this variable falls from 43.7 to 43.2 between 1970 and 1980, and the correlation between the two periods is 0.94 .

${ }^{22}$ The average of the 1970 and 1980 concentration ratios is employed to calculate this variable.
} 


\section{Conclusion}

This paper estimates price-marginal cost mark-ups for Canadian manufacturing industries in order to assess the impact of import competition on domestic market power. The results are mixed. Although the overall relationship between mark-ups and imports is positive across industries for the early 1970s and insignificant for the late 1970s, there is some weak crosssectional evidence to suggest that imports reduce market power in domestically concentrated industries. Changes in imports between the two periods, however, have a positive impact on mark-ups in concentrated industries. Thus, there is no consistent evidence for Canada that imports have had the beneficial impact on competition that has been emphasized in much of the literature. In contrast, an interesting result of the paper is that increases in exports are associated with reductions in mark-ups, suggesting that exports may have a stronger pro-competitive impact on domestic firms than imports. 


\section{Appendix A}

The disturbance term of equation 6' is $\omega_{h}=v_{h}+\xi_{h}$. It is assumed that $E\left(v_{h}, \xi_{h}\right)=0$. The variance of $\omega_{h}, \sigma_{\omega}^{2}$, is therefore equal to $\sigma_{v}^{2}+\sigma_{\xi h}^{2}$. Let $w_{h}$ represent the residuals from an OLS regression of equation 6'. The variance of $\omega_{h}$ can be estimated as follows.

$$
p \lim \left|\frac{w_{h}^{2}}{n-k}\right|=\sigma_{v}^{2}+\frac{\operatorname{var}\left(\Delta \hat{\beta}_{h}\right)}{n-k}
$$

Thus,

$$
\hat{\sigma}_{v}=\left|\frac{w_{h}^{2}}{n-k}\right|-\frac{\hat{\operatorname{var}}\left(\Delta \hat{\beta}_{h}\right)}{n-k}
$$

The first term on the right hand side of equation (A2) can be calculated from the residuals of equation 6' and the second term can be derived from the variance estimates of equation (5) for the individual industries. Equation 6 ' is then estimated using feasible generalized least squares where the observations are divided by $\sqrt{\hat{\sigma}_{v}+\operatorname{vâr}\left(\Delta \hat{\beta}_{h}\right)}$. 


\section{References}

Baldwin, John. 1995. The Dynamics of Industrial Competition: A North American Perspective. Cambridge: Cambridge University Press.

Baldwin, John and M. Rafiquzzaman. 1994. "Structural Change in the Canadian Manufacturing Sector: 1970-1990”. Research Paper No. 61. Analytical Studies Branch. Ottawa: Statistics Canada.

Bound, John, David A. Jaeger and Regina M. Baker. 1995. "Problems with Instrumental Variables Estimation when the Correlation Between the Instruments and the Endogenous Explanatory Variable is Weak," Journal of the American Statistical Association. Volume 90, No. 430.

Bresnahan, Timothy. 1989. "Empirical Studies of Industries with Market Power," in Schmalensee and Willig, editors, Handbook of Industrial Organization. The Netherlands: Elsevier Science Publishers.

Brown, Drusilla and Robert M. Stern. 1989. "Computable General Equilibrium Estimates of the Gains from US-Canadian Trade Liberalization," in Greenaway et al. (eds.). Economic Aspects of Regional Trading Arrangements. New York: New York University Press.

Caves, Richard. 1985. "International trade and industrial organization: problems solved and unsolved," European Economic Review. Volume 28. pages 377-395.

Caves, Richard, M.E. Porter and A.M. Spence. 1980. Competition in the Open Economy: A Model Applied to Canada. Cambridge MA: Harvard University Press.

Cox, David and Richard G. Harris. 1985. "Trade Liberalization and Industrial Competitiveness: Some Estimates for Canada," Journal of Political Economy. Volume 43, pages 115-145.

De Melo, J. and S. Urata. 1986. "The influence of increased foreign competition on industrial concentration and profitability". International Journal of Industrial Organization. Volume 4, No. 3 , pages $287-304$.

Domowitz, Ian, R. Glenn Hubbard and Bruce C. Petersen. 1986. "Business cycles and the relationship between concentration and price-cost margins". Rand Journal of Economics, Volume 17, No 1, pages 1-17.

Domowitz, Ian, R. Glenn Hubbard and Bruce C. Petersen. 1988. "Market Structure and Cyclical Fluctuations in U.S. Manufacturing”. Review of Economics and Statistics.

Geroski, P.A. and A. Jacquemin. 1981. "Imports as Competitive Discipline," Recherches Economique de Louvan, Vol. (47), pp. 197-208. 
Hall, Robert. 1988. "The relation between price and marginal cost in U.S. industry," Journal of Political Economy. Volume 96, pages 921-947.

Harris, Richard G. 1984. "Applied General Equilibrium Analysis of Small Open Economies with Scale Economies and Imperfect Competition". American Economic Review. Volume 74, pages 1016-1032.

Harrison, Ann. 1994. "Productivity, Imperfect Competition and Trade Reform: Theory and Evidence," Journal of International Economics. Volume 36, pages 53-73.

Jacquemin, A., E. de Ghellinck and C. Huveneers. 1980. "Concentration and profitability in a small open economy”. Journal of Industrial Economics, volume 29, pages 131-144.

Katics, Michelle and Bruce Petersen. "The Effect of Rising Import Penetration on Market Power: A Panel Data Study of US Manufacturing". The Journal of Industrial Economics. September 1994, 277-286.

Krishna, Pravin and Devashish Mitra. 1998. "Trade Liberalization, Market Discipline and Productivity Growth: New Evidence from India”. Journal of Development Economics. Volume 56 , pages $447-462$.

Levinsohn, James. 1993. "Testing the imports-as-market-discipline hypothesis," Journal of International Economics. Volume 35, pages 1-22.

Markusen, James. 1981. "Trade and the gains from trade with imperfect competition". Journal of International Economics. Volume 11, pages 531-551.

Markusen, James, Thomas Rutherford and Linda Hunter. 1995. "Trade Liberalization in a Multinational-dominated Industry". Journal of International Economics. Volume 38, pages 95117.

Martins, Joaquim Oliveira, Stefano Scarpetta and Dirk Pilat. 1996. "Mark-Up Ratios in Manufacturing Industries: Estimates for 14 OECD Countries. OECD Economics Department Working Papers, No. 162, Paris.

OECD. 1987. Structural Adjustment and Economic Performance. Paris.

Pugel, T.A. 1980. "Foreign Trade and U.S. Market Performance". Journal of Industrial Economics, Volume 29, pages 119-130.

Roberts, Mark. 1984. "Testing Oligopolistic Behavior, International Journal of Industrial Organization 2, 367-383.

Schmalensee, Richard. 1989. "Inter-Industry Studies of Structure and Performance," in Schmalensee and Willig, editors. Handbook of Industrial Organization. The Netherlands: Elsevier Science Publishers. 